\title{
Developing Playing Activities Model for Anak Suku Dalam Mentawai Based on Modification of Sports
}

\author{
Gusril*, Tjung Hauw Sin
}

\author{
Health and Recreation Department and Sport Coaching Department, Indonesia \\ *Corresponding author. Email: nasir_gusril@yahoo.co.id
}

\begin{abstract}
The purpose of this study is to develop valid, practical, and effective playing activities model. This Research and Development (R\&D) method involved 42 children from a primary school in Madobag Mentawai. The data were collected through questionnaires of playing activities; consisting of close statements and open questions. The data were analyzed using descriptive statistics. A t-test was used to test the effectiveness. Based on data analysis and discussion, it can be concluded that: The process of developing playing activities is done through several steps: analyzing the playing activities of Anak Suku Dalam, designing model, developing of playing activities Anak Suku Dalam, implementing, and evaluating the advantages and disadvantages of model produced is valid, practical and effective.
\end{abstract}

\section{Keywords: Playing Activities Models, anak suku dalam Mentawai, modification of sports.}

\section{INTRODUCTION}

Mentawai is one of the underdeveloped regions that is classified as SMT3 (The Scholars Teaching in the outermost, disadvantaged and frontier regions) area. This area is left behind in all aspects of life, such as education, sports and other aspects of life because Mentawai people live isolated far from West Sumatra Province. In physical education aspect, especially, students were neglected. One of the evidences is that the Physical Education subject is not taught by scholars of the Faculty of Sports Sciences. As a result, students' playing activities are less welldeveloped. Thus, Mentawai always gets no medal when sports championship between regencies / cities in West Sumatra Province (e.g. Porprov XV 2018 in Pariaman) takes place. Given this research, it will be able to overcome the problems of physical educators and also improve the quality of physical educators in the future full of challenges.

\section{Modification of Sports on Playing Activities}

Development of playing activity models is an abstraction of an object being investigated to see the activities of tribal children in Mentawai. Changes in the Physical Education, Health, and Recreation teaching approach were implemented to improve the quality of Physical Education, Health, and Recreation learning which had an impact on the learning outcomes of tribal children in Mentawai. The development of tribal children playing activity models in Mentawai based on sports modification is defined as a systematic application of direct knowledge and understanding to construct playing activity modules used in the Physical Education, Health, and Recreation learning as a material, system or approach including design and development as well as enhancement of new priorities and processes through a newly generated model.
Research development is an activity that describes a new creation of methods, approaches to construct new knowledge according to current needs

\section{Sport Modification}

The etymology of the word modification comes from English "modify" which means to change. Why is the sports modification infused into the Physical Education, Health, and Recreation subject? It is because students are physically and emotionally immature, compared to adults. Problems that occur in the Physical Education, Health, and Recreation learning in elementary schools impede students in several ways, including using tools and regulations that provided for adolescence. It is unquestionable that students are inattentive and less motivated in learning Physical Education, Health, and Recreation. By modifying tools and regulations, it is possible for students to develop strengths more quickly, encourage cooperation among students, and be more pleasure.

In modifying sports, there are four elements that must be considered by the Physical Education, Health, and Recreation teacher, namely: (a) modification of field size; (b) modification of tools and equipment; (c) modification of duration of the game; (d) modification of game rules. Changing the size of the field and playing time aim to reduce the physical demands of students. Modification of tools and equipment include a bat, racket and stick are designed in small sizes which allow students to use them. Likewise, the size and composition of the ball is modified in order to ease students to use them and easily to throw and kick them. In addition, Aussie Sport creates childrensized volleyball with soft materials and painless. For other equipment, the creativity of teachers is required in creating the equipment needed by students. The modification of the duration of the game aims to provide full concentration 
and pleasure for students in carrying out the Physical Education, Health, and Recreation activities. A long period of time bore students while doing the movements. Thus, the teachers must carefully plan the use of time which still consider to the pattern of teaching. Modification of game rules intends to help students develop skills and pleasure in doing sports without ruining the authenticity of the game. Sports modification provides learners with more movement experience than skills. Another expert states that there are several considerations in developing this modification approach: (a) children are physically and emotionally immature, compared to adults; (b) to exercise using modified tools and rules will reduce injury to children; (c) modified sports will be able to develop children's skills faster than standard equipment for adults; (d) modified sports foster joy and pleasure for children in competitive settings [1]. The results of the study states that sport modification can significantly improve the Physical Education, Health, and Recreation learning outcomes [2]. Moreover, the sport modification approach can improve Physical Education teachers' competence in Physical Education, Health, and Recreation learning [3]

\section{Component of Modification}

Components modified in sports comprise of: (a) number of players in each team; (b) the size of the field is scaled down; (c) the duration of the game is shortened; (d) adjust the level of difficulty; (e) simplify the equipment used; (f) change the rules to be simple as needed, so that the game can run smoothly. Furthermore, the expert states that there are several principles that must be considered by the PE teachers: (a) the principle of education is comprehensive; (b) the principle of goal formulation is realistic; (c) the principle of individuality in physical education; (d) the principle of prioritizing pleasure and freedom of movement; (e) the principle of equal and comprehensive participation; (f) the principle of prioritizing successful experiences and $(\mathrm{g})$ the principle of task modification [4].

\section{METHODOLOGY}

This qualitative research employed the research and development approach. This study developed a valid, practical and effective play activity models for tribal children. In developing play activity models for tribal children in Mentawai, ADDIE model was applied which is started from analysis, design, development and evaluation and implementation [5].

Furthermore, the playing activities, the goals of the game, and the type of games performed by tribal children in Mentawai were analyzed. Then, the types of games performed were grouped according to the types of games classified into sports and traditional sports, sports that use big balls, small balls, equipment, without equipment, and traditional games. Next, the playing activities models were designed according to the type and the purpose of the game.

\section{RESULTS AND DISCUSSION}

Data Analisys and Results of Developments Analysis Stage

The first step was to analyze the Physical Education, Health, and Recreation curriculum: analysis of curricular objectives, analysis of core competencies, basic competencies, and indicators contained in Physical Education, Health, and Recreation learning material in the $5^{\text {th }}$ grade and their learning materials. Next step was to analyze the level of playing activities of tribal children in the Mentawai. Besides, a comparison of male and female playing activities was also analyzed. In this case, it also included learning material in the $5^{\text {th }}$ grade of elementary school. The infrastructures supported materials that set out in the curriculum. The Minister of Education and Culture's regulation provided an opportunity for PE teachers to use learning material from traditional games performed by tribal students in the Mentawai. Therefore, there was a link between children's activities in school and outside the school. This certainly would increase the motivation of tribal children in Mentawai in carrying out Physical Education, Health, and Recreation learning activities. As a result, the learning outcomes of Physical Education, Health, and Recreation subject of tribal children in Mentawai would certainly increase.

Based on the results of the analysis and discussion, it can be concluded as follows:

1. Playing activities of children of Suku Dalam Madobag Mentawai Regency is in a fair category and there is no significant difference between boys and girls in playing activities.

2. The process of developing playing activities is employed through several stages: (a) analyzing of playing activities, (b) designing the models by paying attention to game names, goals, facilities, rules, and fields, (c) developing the models by modifying game field, rules, duration, tools and determination of the losers and winners.

3. There is a valid, practical and effective model of playing activities of tribal children in Mentawai.

Analysis of Playing Activities

Data of playing activities for boys and girls of tribal children in Mentawai

1. Data of Playing Activities of Children (Boys)

Based on playing activities data, it was obtained that the highest score was 113 and the lowest score was 78 . Based on the data analysis, it was found that the average score was 98.82, the standard deviation was 9.34, the median was 99 and the mode was 96 . The frequency distribution score of playing activities for tribal children in Mentawai (boy) can be seen in the following table. 
Table 1. Playing Activities Distribution of Boys.

\begin{tabular}{|c|c|c|c|}
\hline $\mathrm{NO}$ & Interval & $\mathrm{Fa}$ & Fr (\%) \\
\hline 1 & $78-84$ & 2 & 8,70 \\
\hline 2 & $85-91$ & 3 & 13,04 \\
\hline 3 & $92-98$ & 6 & 26,09 \\
\hline 4 & $99-105$ & 5 & 21,74 \\
\hline 5 & $106-112$ & 6 & 26,09 \\
\hline 6 & $113-119$ & 1 & 4,35 \\
\hline \multicolumn{2}{|c|}{ Total } & 23 & 100,00 \\
\hline
\end{tabular}

The table shows that from 23 students, 2 students $(8.70 \%)$ were in the value of $78-84,3$ students $(13.04 \%)$ were in the value of $85-91,6$ students $(26.09 \%)$ were in the value of $92-98,5$ students $(21.74 \%)$ were in the value of $99-105,6$ students $(26.09 \%)$ were in the value of 106 112,1 student $(4.35 \%)$ was in the value of $113-119$. For more details on playing activity variables (boys), it can be seen on the following histogram:

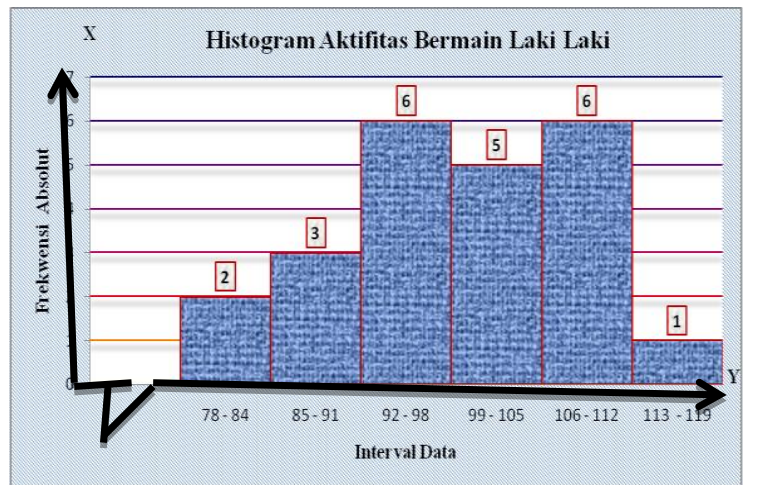

b. Data of Playing Activities of Children (Girls)

Based on playing activities data, it was obtained that the highest score was 113 and the lowest score was 87 . Based on the data analysis, it was found that the average score was 100.57 , the standard deviation was 6.70 , the median was 102 and the mode was 97 . The frequency distribution score of playing activities for tribal children in Mentawai (girls) can be seen in the following table.

Table 2. Playing Activities Distribution of Boys.

\begin{tabular}{|c|c|c|c|}
\hline $\mathrm{NO}$ & Interval & $\mathrm{Fa}$ & $\operatorname{Fr}(\%)$ \\
\hline 1 & $87-91$ & 2 & 10,53 \\
\hline 2 & $92-96$ & 2 & 10,53 \\
\hline 3 & $97-101$ & 5 & 26,32 \\
\hline 4 & $102-106$ & 7 & 36,84 \\
\hline 5 & $107-111$ & 2 & 10,53 \\
\hline 6 & $112-115$ & 1 & 5,26 \\
\hline \multicolumn{2}{|c|}{ Total } & 19 & 100,00 \\
\hline
\end{tabular}

The table shows that from 19 girl students, 2 students $(10.53 \%)$ were in the value of $87-91,2$ students $(10.53 \%)$ were in the value of $92-96,5$ students $(26.32 \%)$ were in the value of $97-101,7$ students $(36.84 \%)$ were in the value of $102-106,2$ students $(10.53 \%)$ were in the value of $107-111,1$ student $(5.26 \%)$ was in the value of 112 -
115. For more details on playing activity variables (girls), it can be seen on the following histogram:

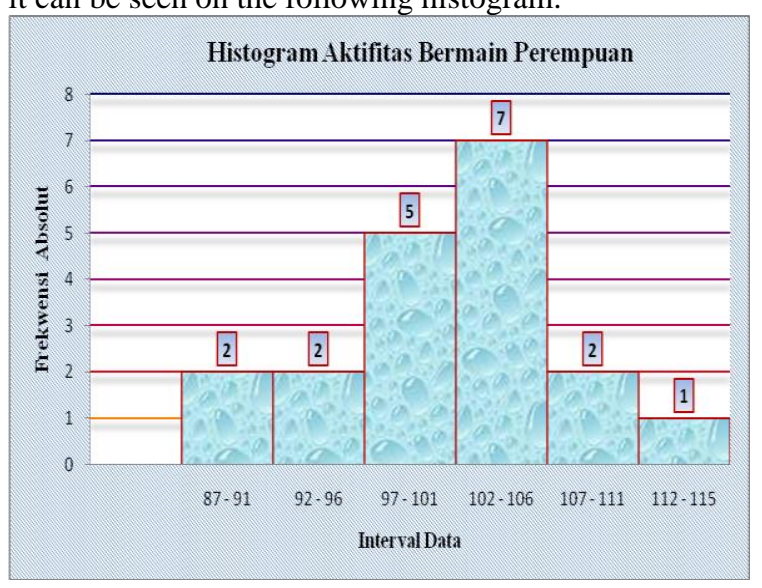

The results of statistical discrimination tests between playing activities of boys and girls did not have a significant difference. In that sense, there is no significant difference in playing activities of boys and girls in the level of play activities.

The types of games performed by tribal children in Mentawai consisting of: running, long jump, high jump, shot put, football, volleyball, basketball, rounders, badminton, gymnastics, takraw, canoe or rowing, archery, marbles, rubber hop, tigers and cats, cats and dogs, slingshot, seesaw, Main kucing, Main Gundu

Designing

In developing the playing activities models of tribal children in Mentawai, it was based on sports modification by paying attention to the syllabus and learning patterns of the Physical Education, Health, and Recreation. In developing the playing activities models, it employed sports modification approach in the form of modules and model books that will be used by PE teacher in Physical Education, Health, and Recreation learning. The development of the models refers to theories taken from various kinds of theories about playing activities and model development.

Developing

The development of the playing activity model was done by analyzing the playing activities of tribal children in Mentawai, including: the condition of playing activities for tribal children between boys and girls, the comparison of playing activities between boys and girls and the types of games performed by tribal children in Mentawai. Then, the activities performed are grouped according to their types.

Implementation

The implementation of playing activity models based on sports modification was employed by involving Physical Education, Health, and Recreation experts and other experts related to models and languages. Based on the results of expert opinion, the playing activities model using a sport modification approach was in accordance with the needs. Then, limited experiments were conducted 
on the $5^{\text {th }}$ grade for 16 meetings. Based on the results of the implementation, it can be concluded that there is an increase in learning outcomes of Physical Education, Health, and Recreation in tribal children in Mentawai. From the learning outcomes of Physical Education, Health, and Recreation, it can be concluded that the playing activity model using sports modification is effective in improving the learning outcomes of tribal children in Mentawai.

\section{Evaluation}

Evaluation on the implemented model was something that must be concluded. The results of evaluation on the implemented model was a model that can be used by PE teachers in learning in schools with their strengths and weaknesses. The strengths of this model are: (a) a form of activity that is familiar to the tribe children in Mentawai; (b) activities do not require standard fields and equipment; (c) the physical activity of tribal children of is categorized high in doing Physical Education, Health, and Recreation activities; (d) Activities done are quite varied according to the wishes of tribal children in Mentawai; (e) the neglect of Physical Education, Health, and Recreation learning can be overcome. The weaknesses of this model are: (a) it needs time-consuming adjustments because there is a new form of playground development; (b) there are some difficulties in developing game tools such as: archery equipment is quite difficult to make.

Based on the evaluation results, it can be concluded that this model is valid, practical and effective in improving the learning outcomes of tribal children in Mentawai. The results of the study state that the playing activity model of tribal children in Mentawai using sports modification approach is practical and effective in improving the quality of Physical Education, Health, and Recreation learning. Learning material starts from what they do in the daily playing activities of tribal children in Mentawai. Besides, field, equipment, rules and forms of play are modified. If it is observed, the participation of tribal children in Physical Education, Health, and Recreation learning is increasing. This is what is most needed in Physical Education, Health, and Recreation learning: playing activity increases and the experience of movements increases as well. The results of the classroom action research state that sports modification can improve the learning outcomes of Physical Education, Health, and Recreation of the $5^{\text {th }}$ grade students in Sekolah Dasar Negeri 4 Pekanbaru, Indonesia (Padri, 2016).

\section{CONCLUSION}

Based on the data analysis and discussion, it can be concluded the following: The process of development of playing activities is done by analyzing playing activities of tribe children in Mentawai, designing the model, developing of playing activities of tribe children in Mentawai, implementing and evaluating the strengths and weaknesses of model produced is valid, practical and effective.

\section{REFERENCES}

[1] Bahagia, Yoyo. "Pengembangan Media Pengajaran Penjaskes". Jakarta: Depsiknas Dirjen Pendidikan Dasar dan Menengah Direktorat Pendidikan Luar Biasa. 2003, pp 45-54

[2] Padri. "Peningkatan Hasil Belajar PJOK Peserta Didik Kelas VB Sekolah Dasar Negeri 4 Kota Pekanbaru". (Tesis) Program Pascasarjana UNP. Padang: PPS UNP. 2016, pp 23-34

[3] Gusril. "Peran Modifikasi Olahraga Dalam Peningkatan Kompetensi Guru PJOK Dalam Pembelajaran". Jurnal Elektronik Jurusan Kesehatan dan Rekreasi FIK UNP, Padang. 2018, pp 12-23

[4] Lutan, Rusli. "Asas-Asas Pendidikan Jasmani Pendekatan Pendidikan Gerak dan Belajar Gerak", Jakarta: Dirjen Pendidikan Dasar dan Menengah Depdikbud. 2001, pp 15-45.

[5] Gusril. "Penelitian Pengembangan Dalam Ilmu Keolahragaan”. Jakarta: Rineka Cipta Press. 2016, pp 47-60. 